\title{
XXIII. On the ancient and modern formation of delta in the Persian Gulf by the Euphrates and Tigris, in answer to Mr. Beke
}

\section{W.G. Carter Esq.}

To cite this article: W.G. Carter Esq. (1835) XXIII. On the ancient and modern formation of delta in the Persian Gulf by the Euphrates and Tigris, in answer to Mr. Beke, Philosophical Magazine Series 3, 7:39, 192-202, DOI: 10.1080/14786443508648694

To link to this article: http://dx.doi.org/10.1080/14786443508648694

曲 Published online: 01 Jun 2009.

Submit your article to this journal $\pi$

Џll Article views: 2

Q View related articles $\sqsubset$ 
propositions without reference to anything but the most common propositions of the theory of limits. Or at any rate, I feel certain that all who would be able to specify an objection will easily discover what are the processes which I consider as proofs. I therefore do not think it necessary to give the proofs, and my only object in writing this letter has been to call attention to the possibility of establishing this celebrated theorem by methods which certainly do not lie open to any objections arising from assumptions relative to expansion of functions.

London, July 20, 1835.

I remain, Gentlemen, yours, \&c.

XXIII. On the Ancient and Modern Formation of Delta in the Persian Gulf by the Euphrates and Tigris, in answer to Mr. Beke. By W. G. CArTer, Esq.

\section{To the Editors of the Philosophical Magazine and Journal.} Gentlemen,

A FTER so long an interval, and when the points in discussion between Mr. Beke and myself must be nearly forgotten, I reluctantly enter on it anew. The manner, however, in which that gentleman has met and has construed my remarks in your October Number renders some notice unavoidable.

I quite concur in leaving the question, - what was the gopher wood of the ark? - where that discussion has placed it, and in so doing shall not superadd a remark to awaken it.

The topic more likely, perhaps, to engage attention at this moment, thrown into that inquiry, relates to the supposed extraordinary power of the Euphrates, Tigris, and neighbouring streams to form new land and expel the ocean, Mr. Beke still adhering to the theory which carries the Persian Gulf, at the date of the building of Babel, or about 100 years after the Flood, to the site of Babylon and beyond it to nearly one third of that extent. Col. Chesney makes the distance from the gulf to Hillah on this spot 451 miles*, so that the amount of land formed by the deposits of the rivers since about A.M. 2452 is on this hypothesis of no less length to travel over than 580 miles, or, in a line (adopting the $\frac{3}{4}$ ), 435 .

Seeing, however, that Plinyt, the great authority for this theory, informs us in a passage to which we are referred that much earlier than his day (A.D. 78) a junction, which we now India.

* Report of Committee of House of Commons on Steam Navigation to + Pliny, Hist. Nat., l. vi. c. 27. 
see, had even then taken place between the Euphrates and the Tigris, and that a long space then also existed between that junction and the sea, the first glance at this author seemed to me rather to give a direct negative to the whole matter.

But going back 400 years before Pliny, to the reign of Alexander the Great, I adduced in my last paper the voyage of Nearchus, illustrated by the masterly exposition of that subject by Dean Vincent, and the navigation of those rivers performed by Alexander and his fleet, as affording conclusive facts in proof that the broad outline of the coast had, as to any point in question between Mr. Beke and me, undergone no material change for the last 2200 years. This is all passed over in the reply; but it states that I had "asserted the fact," " much strained and qualified many ancient authorities," and then, from some early measurements, in all their uncertainty, which Pliny, while he gives them, points out, it concludes that " a very considerable advance of land" (the great delta, I presume, " "is a fact established beyond dispute." "Not quite so, 1 apprehend. Let us examine a little.

A delta which has been forming during 3300 years, and whose formation is said to have been in high activity at the end of 1600 , or the commencement of the Christian æra, can offer no territory, in the whole or nearly the whole of any line of its extent, which was the scene of very early events. Take Susiana, being that part of it on the east or north-east of the Tigris. Its capital, Susa, is said to have been founded by Tithonus*, father of the celebrated Memnon; its origin, in fact, lost in remote antiquity, but pointing to about 1200 years B.c., at less than a ninth of this delta's present age. Nebuchadnezzar, about 600 B.c., had a palace at Shushan (probably Shuster), on the Susian Ulai or Euleus. Susiana was one of the satrapies of Darius Hystaspes, 500 B.c. $\uparrow$ 'Turning to this delta's longer line, let us take the Babylon of Nebuchadnezzar. At that time the city being about the site of Hillah, there could have been, on this theory, little or no advance of the delta beyond it. We have now, at the lowest calculation, on the common chronology, less than a thousand years to the division of the lands, and yet in the time of Isaiah, more remote still by nearly two hundred years, the identical Chaldean Babel is spoken of as a settlement of the earliest antiquity. "Behold," says Isaiah, "the land of the Chaldeans; this people was not, till the Assyrian founded it for them that dwell in the wilderness: they set up the towers thereof, they raised up

* Strabo, 1. xv. 729. $\uparrow$ Herodotus, Thalia, 91.

Third Series. Vol. 7. No. 39. Sept. 1835.2 C 
the palaces thereof*." No one can doubt that this refers to the celebrated Babylon. We are here, then, close upon Peleg, with a settlement and colony at the end of a delta, intruding 135 miles on a site which the supposed gulf of his day covered.

I must now return to the country of Susiana, further to show by its ancient limits, and the navigation of Alexander the Great and his officers, how little ground there is for the addition to the delta of the $245(453-206)$ miles, - too little, as it is, for the theory, - said to have been made since that period.

The remarkable river Arosis, or Oroatis, now called the Endian, and in the country, Tabt, or 'the river', by way of preeminence, following on from the coast of the delta, formed with the gulf, and identifies, its south or south-eastern boundary. Thus Ptolemy $\ddagger$ makes that boundary, the gulf from this river to the Tigris. Nearchus, we shall find, says the same. Strabo $\S$ mentions the Oroatis as the Persian boundary, and adds that all the rivers which flow through Susiana fall into the channel of the T"igris and the intermediate canals of the Euphrates. Here we have, too, as in Pliny, distinctly the junction of the rivers, a considerable space between it and the sea, and the united stream, called by Strabo the Euphrates, thus corresponding to the state of the country at this day.

Now, let us take the navigation of Nearchus and his fleet from the mouths of this river Arosis (325 B.c.). In going thence along the coast of Susiana, he tells us $\|$ " that the place was very marshy, and that the shoal extended far into the sea.... They came to anchor at Kataderbis....Thence sailing away, the ships were led one by one through narrow channels; stakes fixed on both sides pointed them out." Thus they proceeded, and the next day from Kataderbis came to Diridotis, on the south-west point of the delta; so that instead of having a voyage of ten or eleven days, which the present theory would give them, they arrived from the boundary stream of Susiana on the opposite side, by a very difficult and dangerous course, on the third day from starting. On this topic the reply is silent, and it is the more remarkable because Mr. Beke says, " in reply to Mr. Carter, I ought, perhaps, to confine myself to the consideration of Nearchus's statement alone."

* Is., ch xxiii. v. 13.

+ Vincent's Commerce and Navigation of the Ancients, vol. i. p. 418.

I Ptolemy, 149. \& Strabo, l. xv. 728.

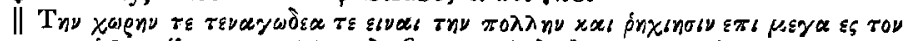

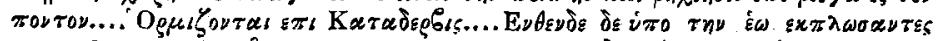

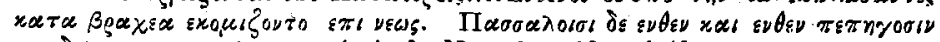

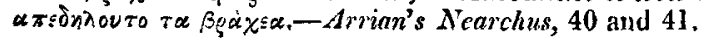


Then as to the navigation of Alexander and his fleet in the delta streams. Arrian thus gives it*: Alexander, having joined his fleet at Susiana, "sailed down the river Euleus towards the sea; and now when near its outlet to the ocean, he left the worst and greater part of his ships, and with the swiftest sailed down the Euleus to the ocean and to the mouths of the Tigris, the other ships on the Euleus entering a canal cut from the Tigris to that river." He thus made a circuit to meet them. And all this might be done at the present time. The ancient canal, the entire circuit, all the points of the navigation then presented by the spot, are still offered for our observation. The Euleus, coming from the north-east in a line perpendicular to that of the 'Tigris, actually marks off and fixes the extent of the delta of that period. Or are we, for the purposes of this theory, to suppose some other river? flowing too through Susiana, which lies in part at the end of a line from the lower Euphrates + , carrying its waters to a delta 200 or 300 miles to the north-west, and another canal cut across from it to some high quarter of the. Tigris, adapting itself to the occasion? But that is impossible; the theory throws an expanse of gulf in its way, into which any river from Susiana which could be substituted must have fallen, remote from the Tigris.

On my " much straining and qualifying many ancient authorities," I do not think it necessary to enter, especially as they ail harmonize with the unbroken sense of the passage in Pliny, in part quoted by $\mathrm{Mr}$. Beke, and to which I shall presently refer. My observation, distinctly applied to Pliny's general account of the two rivers only, that gentleman at once iransfers to all the authorities adduced, and then adds, "on his own admission they are not always very explicablef."

But the main point on which Mr. Beke now rests his argument is the measurement of distances given by Pliny. The quotation from that author which seemed the most to favour

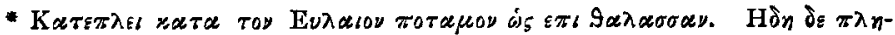

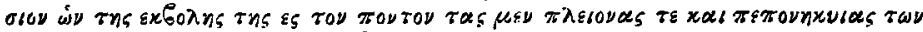

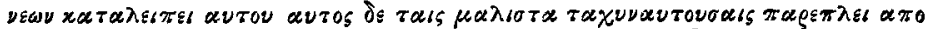

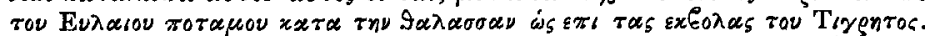

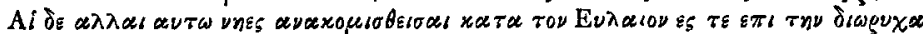

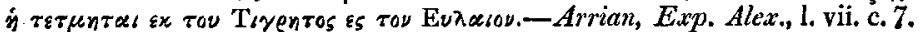

+ See Col. Chesney's Map in Report.

A few miles of addition to the delta has manifestly never been the question. I much object to such expressions in the reply as, "Mr. Carter has, in fact, asserted the opinion, that since the time of Nearchns, the encroachments on the gulf must be very unimportant," omitting the words "to the point in question, any later encroachments,"'sc., as conveying the idea of a mere assertion without proof, and a much broader one than my remarks warrant.
} 
it was, that in ancient times a space of several miles existed between the mouths of the two rivers, because it led us to infer that all this space had been since filled up by the growth of the delta. In my last paper I pointed out a serious oversight; for Pliny immediately goes on to say, " but long since the Orcheni and neighbouring people had dammed up the Euphrates to water the fields, so that by the Pasitigris only it is now carried to the sea*." I should not here notice the important loss to the theory of this passage, but that the reply does not, and a similar instance occurs.

I had there made a pointed reference to the following statement of Plinyt: "Nearchus and Onesicritus relate, that the length of the voyage along the Euphrates, from the Persian sea to Babylon, is 412 miles;" (then follows the distance from Seleucia;) then, "Juba says, from Babylon to Charax is $\mathbf{1 7 5}$ miles.... Some say that beyond Babylon it keeps in one channel for 87 miles, till parted at the irrigating canals.... From such varying relations it is difficult to learn the true measure.... Where it ceases to keep its channel on the confines of Charax," \&c. So that we have for the distance in miles to Babylon 412, with Juba's 50 to Charax also 225, and a third in this 87 only to about Charax. The length of the stadium is not the point here. Indeed, having examined several distances in Strabo and Pliny, I believe 16 to a mile, notwithstanding their rule (infra) will sometimes correspond fully as well as any other. The point is, that the distance was utterly uncertain. Pliny knew not, could not know, what to determine, and consequently whatever he has related of an increase in the distance of Charax from the sea, and thus of some large accessions to the land, must rest on the slippery basis of this "diversitas auctorum".

The reply, however, having in the preceding paragraph introduced Dean Vincent to say that Nearchus not having personally made the estimate, it could not be relied on, detaches it from the rest, and thus presents it: "We fortunately possess an anthority independently of Arrian $\ddagger$, who establishes

* Pliny, Hist. Nat., l. vi. c. 27. And it is the more remarkable, for Pliny actually mentions this junction of the Euphrates and Tigris no less than three times in the same sixth book, and notices there also, specially, the confluence of the Tigris and Euleus.

+ Euphrate navigari Babylonem e Persico mari 412 mill. pass. tradunt Nearchus et Onesicritus...Juba a Babylone Characem 175 mill. pass.... Fluere aliqui ultra Babylonem continuo alveo priusquam distrahitur ad rigua 87 mill...Inconstantiam mensuræ diversitas auctorum faeit... Ubi desinit alveo munire ad confinium Characis, \&c. - Pliny, Hist. Nat., 1. vi. c. 26.

† Pliny had learned this from some quarter, but why is he to be considered in authority independently of Arrian for the 3300 stadia? He ex- 
that historian's correctness upon this subject in all points. This authority is Pliny, or rather Juba as cited by Pliny, who states, 'Euphrate navigari Babylonem e Persico mari 412 mill. pass. tradunt Nearchus et Onesicritus." Who conld suppose there was such a sequel? Yet this insulated notice, labouring under all the uncertainty as to Nearchus's correctness and Pliny's alleged error and avowed difficulty, with his account of discordant measurements in the first part of the same river voyage, as far as Charax, are the important points in support of the theory; the main difference between the whole and the part appearing to be, that the number of miles in the one is from the higher to the lower, in the other from the lower to the higher; but as both seem to give them in the order of time in which they were taken, it is unaccountable that Pliny should hence have inferred, as he seems to have done, that the differences in the first part of the voyage,-differences, too, not corresponding with those of the whole distance, and from which the confusion he complains of had chiefly arisen,should lead him to reconcile the former only by the notion that a large increase had therefore been made to the land; and certainly serious doubts may thus well arise of the authenticity of the latter passage.

The reply, to remove a difficulty about the distance of Charax from the sea, would suppose " the more correct construction" to be, that this city was built by Alexander 50 miles inland, Pliny having stated it in his time to be 120, thus making the whole advance of the delta, from Alexander to Pliny, 70 miles only. And we bave seen, that long before the latter, the two rivers met and passed in one channel to the sea. Now, we shall not, I presume, be required to believe, that not only an addition of some 200 miles of land has been made to this delta since Pliny wrote, but also that the rivers have separated, formed each a channel over it, and then again formed a junction and another joint channel, in due correspondence with

pressly says, "Priusquam hæc generatim persequamur indicare convenit quæ prodit Onesicritus classe Alexandri circumvectus in Mediterranea Persedis ex India narrata proxime a Juba ;" and he tells us, "Onesicriti et Nearchi navigatio nec nomina habet mansionum nec spatia." Yet, as Salmasius observes (830), Nearchus's account relates both very fully, and "Plinius ex auctore Onesicriti eamdem retulit mirum quanta diversitate." Had Pliny or Juba known much of Arrian's Nearchus, would they have followed the loose story of Onesicritus? There is an authority, however, for about 3000 stadia, and it is Strabo; but we know that Strabo's rule was the stadium of 8 to a mile. He makes the distance from Thapsacus (El Deir) to Babylon 4800 stadia; adding the 3300 thence to the sea, we get 8100 , which, at 8 to a mile, is 1012 miles : Col. Chesney makes it 1025 miles (Strabo, $x v$. 146. Report, \&c.), a difference between the ancient and modern admeasurements of 13 miles only. If measurements are to decide on the growth of the delta, what has been offered so conclusive as this? 
his account of them. This surely will not be supposed. But unless it be, what becomes of all that is said there, and before and after this, in the next sentence, is repeated, about Pliny's error? The 3300 stadia which Alexander's officers had reckoned it from the sea to Babylon, here at least, could not possibly have been the stadia of 16 to a mile, or $206 \frac{1}{2}$ miles only. If the distance of Charax, the port, had increased but 70 , the whole distance to Babylon could have increased but 70 ; and then "it is yet further to be considered" whether even this 70 is not to be reduced, in fact, to 35 only; so that without the above extravagant hypothesis, the great point of 245 miles more of delta since the voyage of Nearchus (B.c. 325) is thus at once disposed of *.

It is due to Dean Vincent (whom the reply unceremoniously throws overboard + ) to say, that no one felt the difficnlty of adapting a fixed standard of ancient measurement to his subject more than he did. In employing, with M. D'Anville, the so-called stadium of Aristotle, he admitted that it is not to be found in Aristotle; that it is not, " perhaps, possible to measure 500 stadia in any detached portion of the [Nearchus's] course with satisfaction;" that the stadium of the generality of ancient writers is eight to a Roman mile; and that $D^{\prime}$ 'Anville's measures "still leave some obscurity behind f." Major Rennell insists on a much longer one than Aristotle's§. Pliny i| and Strabof, who both mention Nearchus's voyage and the distance to Babylon, both notice the stadium as being that of eight to a mile, and Dr. Falconer, after $\dot{a}$ learned investigation, concludes this to be the stadium of Arrian and the other earlier writers. Surely the length of the stadium offers no sound basis for a theory**.

But Mr. Beke says I have not touched upon the geological

* And withont supposing all this, even the increase of 35 is annihilated by the plain fact, that it is now but 62 miles even to Bosra. The junction of the Susian river is about 20 miles lower down (see Col. Chesney's map in Report). We are to place Charax 5 miles still lower, and even halving the 120 of the merchants and Arabs, (on which the inference is made to rest,) we have then 60 to the sea, while at the present moment, from the same spot, it is thus but about 35 miles only.

+ Malte-Brun seems to have been quite as nearsighted on the general topic as the learned Dean, for he observes of the mighty Indus and its farspreading tributaries, "From the voyage of Nearchus we should learn, that notwithstanding the immense tides, the coasts, at the mouth of the Indus, have not been sensibly changed since the time of Alexander." (Universal Geography, vol, i. book 18.)

¥ Vincent's Commerce, \&c., Prelim. Dissert., 9.

$\oint$ Geography of Herodotus, seet. 2.

II Pliny, Hist. Nat., l. ii. c. 23.

If Strabo, 1. vii. 322.

* Dr. Falconer's Arrian's Voyage, Discourses, \&c., p. 184. 
portion of the argument. I have not found it. The mere fact that rivers form deltas and produce more or less changes on the surface, and that these rivers have done so, no one disputes. I believe this delta's existence is now disproved by history. But a word or two on the desired topic.

There seems no other doubt than that in discussion, that all below Felujah, or thereabouts, in the course of the Euphrates, has been, at some period, geologically modern, a part of the desert, and, like all sandy deserts, once covered by the ocean: that accounts for its level character. And, from the tendency which the waters of an inlet of the ocean, like that supposed, have to rise, as have long been known in the instance of the Red Sea, I fear, paying no respect even to the wide boundaries now given to it, it must necessarily have travelled over all the Arabian desert. What was to stay it? The gulf current drives that way. The protecting slip of country was not yet raised by the ordinary deposits of the river. The measure of this delta is clearly the extent of the level. That slip is no true exception. On the principle adopted, all the desert has an equal claim. But in forming deltas, rivers do not construct sandy deserts; so that is excluded.

In the opening made by Alexander to the Pallocopas, in order to limit the efflux of water, and therefore, probably, at no great depth, the workmen appear to have come to rock

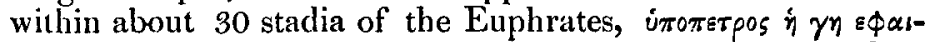
$v \varepsilon \tau \alpha$. From the context this was plainly not mere gravel,a very unlikely discovery many miles laterally within, and some 200 from the head of, a delta *.

A river, in producing a delta, forms both its own bed and channel necessarily, at first, in the proximate line of its course. If it can thus obtain a sufficient slope, (and where does it?) the channel thus formed will also necessarily be nearly straight; but as the inclination which its delta acquires, in either a direct or transverse line, must be very moderate, the stream naturally divides into several channels. Both these rivers, however, and especially the Tigris, instead of pursuing a direct course, are here tortuous and serpentine, and, for the most part, keep each within a single channel. The Tigris passes over the alleged delta in a rapid stream, consequently finds a considerable slope; the Euphrates from above Felujah, for upwards of 600 miles, in a dull and lingering stream, consequently with scarcely any, and to its low level the Tigris, "very different in every respect + ", at length bends its course and joins it at

* Arrian, Exped. Alex., l. vii. c. 21.

+ Col. Chesney's Evidence and Remarks in Report. 
Khorna*. From Khorna, then, there must be an ample rise north-west along the course of the Tigris, and from it a descent south-west towards the level of the Euphrates; and as the rivers of Susiana run in this direction $t$, there must be a further rise over the delta through Susiana to the mountains. Whilst, on the other hand, the current of the gulf setting strongly from the north-east to the south-west,-from the direction of the Tigris towards that of the Euphrates, - must, on this theory, rather have raised the relative level of the Euphrates' channel throughout the mighty embankment.

But we see the rise is, in fact, the other way, and it is manifestly impossible to reconcile the degree and extent of this variation of level and the general phænomena of the supposed delta, with the existence here of such a formation. Indeed, were it so, the Tigris, in thus constructing its own bed and channel, must necessarily have done it in the direction of the declivity torwards the Euphrates; and thus, at the earliest stage of this progress, would inevitably have fallen into the channel of that river. We should then have had, for a short space, the united stream in one channel, which would doubtless, as in other instances, and as these waters do below Bosra, have spiead out into diverging streams till they reached the gulf.

And, now, on this topic, to revert to the point we started from, the gulf being 580 miles up the country 100 years after the flood. Even supposing for a moment all that extent of land to be the production of this agency, it is geologically a little singular that the inquiry did not arise, What connexion has that event with the topic? It has before been admitted, that it

* Both at a very early and in the present day clouds have hung about this topic. Arrian, 1. vii. c. 7., says expressly, the Euphrates has a higher channel than the Tigris, which receives the waters of the Euphrates by many streams. Prof. Heeren (De la Politique, \&c. de l'Antiquité,Fr.ed., vol. ii. s. 2.) refers to, and seems to have been misled by, this passage, for though he quotes from the proceedings of the Bombay Society, "the tide passes up the Euphrates for 20 miles above Khorna, and stops there at the mouth of the Tigris," (Mr. Barker in Evidence, Report, \&c., says there is no perceptible tide at Bosra, 12 miles below Khorna,) to show that the Tigris is far the more rapid river, he overlooks the fact that it can be more rapid only through flowing from a higher country down a greater slope. Xenophon understood this better: he mentions four canals by which the latter pours its waters into the Euphrates (Anab., 1. j. c. 7.). The same may be inferred from Justin (42. 3.); and Captain Chesney (Report, \&c.) informs us of the canal of "the Hie by which the Tigris gives a large contribution to the sister stream," about 220 miles above the gulf. The error may have arisen from the Euphrates having raised its bed above the immediate level over which it passes. Its waters, therefore, would run from it through the irrigating canals till they came to the rise towards the Tigris.

+ Strabo, I. xv. 728 . 
changed neither the character nor the products of this country. Did not its waters come hither and return as in other places it might reach? Might not these rivers have run, and their joint delta been formed, thousands of years before the cataclysm? Geology knows of none other than relative dates. Thus, were even the delta established, we should yet be no nearer to the proof that the gulf was in its site in the days of Peleg.

Mr. Beke, with much candour, relinquishes the reading of Gen., x. 11, that Asshur was the person who built Ninevel, and adopts the opinion that Asshur (or Assyria) was the country and Nimrod the builder; though it appears from the sequel that he still adheres to a second Babel in the Babylon of the Chaldeans. But as Shinar must have embraced no very extensive range, - for its little chief and three others Abraham and his servants vanquished, - and Nimrod's Babel (or Babylon) and the Babylon of the prophets were in it, that we have here two places of the same name,-both moreover, as we have seen, built in the very infancy of society, and both by " the Assyrian", is, I apprehend, an inference not sanctioned by true historical construction.

The opinion, however, is repeated, of the improbability, at all events, of cities having been built (or, more properly, of settlements having been made), at the earliest post-diluvian age, in the low lands of the Eaphrates. No allusion is made to my answer that the cities and settlements of a hot climate, and more particularly those of an early people, are of necessity, and that the earliest on record were, in fact, fixed in such places. The travellers from or towards the east settled in "a plain", and any plain in which they could then have settled becomes immediately liable to all the objections made to that spot, in which the history, according to every authority, I believe, (save Drusius, says that they did settle. Col. Chesney's evidence*, relieves us fiom further discussion. He tells us that along the Euphrates " it is no uncommon occurrence to see a whole village aftoat, and the people following it on foot or in their canoes to arrest the materials of their dwellings." In a cold climate we have little notion of the value of water to the inhabitants of a hot one. Here, however, we have the Nimrods of the present day, in spite of the experience of nearly 4000 years, doing just what their own and the other earliest patriarchs did before them, who, heedless of all the good reasons to the contrary, seem to have chosen for their little settlements every such impracticable spot they could find. They built Nineveh

* Report of Committee of House of Commons, \&c.

Third Series. Vol. 7. No.39. Sept. $1835 . \quad 2$ D 
202 Mr. Jerrard on solving Equations of the Fifth Degree.

" of old like a pool of water," Calneh, Babylon, \&c. " in the low lands of the Tigris and Euphrates"; they resorted to the valley of the Nile, fearless of the "flood of Egypt"; and they peopled the vale of Siddim in the plains of the Jordan, "which overflowed all its banks in the time of harvest".

[To be continued.]

XXIV. On certain Transformations connected woith the finite Solution of Equations of the Fifth Degree. By G. B. Jerrard, $A . B$.

To the Editors of the Philosophical Magazine and Journal. Gentlemen,

SOON after I had discovered, by the method of investiga$N$ tion contained in Part ii. of my "Mathematical Researches", that the second and third terms of the transformed equation in $y$ might be made equal to zero, independently of one of the indeterminate quantities, $Q$, involved in the expression for $y$, and that consequently the general equation of the fifth degree might be reduced to any one of the trinomial equations

$$
\begin{aligned}
& x^{5}+\mathrm{D} x+\mathbf{E}=0 \\
& x^{5}+\mathbf{C} x^{2}+\mathrm{E}=0 \\
& x^{5}+\mathbf{B} x^{3}+\mathbf{E}=0 \\
& x^{5}+\mathbf{A} x^{4}+\mathbf{E}=0
\end{aligned}
$$

I perceived, on comparing these forms with the solvable ones which were known to mathematicians, that had it been proposed to arrive by a direct process at the third of these equations,

$$
x^{5}+\mathrm{B} x^{3}+\mathrm{E}=0,
$$

and at De Moivre's solvable form,

$$
x^{5}+\mathrm{B} x^{3}+\frac{1}{5} \mathrm{~B}^{2} x+\mathrm{E}=0,
$$

the same analytical difficulty arising from the dimensions of the equations of condition must in both instances have been overcome; since in the former case it would have been necessary to make

$$
\mathrm{A}=0, \mathrm{C}=0, \mathrm{D}=0,
$$

and in the latter,

$$
\mathrm{A}=0, \mathrm{C}=0, \mathrm{D}-\frac{1}{5} \mathrm{~B}^{2}=0 .
$$

This led me to suspect, notwithstanding the almostoverwhelming weight of authority which pressed against the supposition, that there must be some defectiveness in the train of reasoning by which MM. Ruffini and Abel (in following out the views 